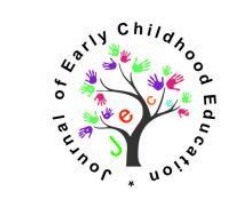

Available online at JECE (Journal of Early Childhood Education)

Website: http://journal.uinjkt.ac.id/index.php/jece

Permalink/DOI: http://dx.doi.org/10.15408/jece.v3i1.20229

JECE, 3 (1), Juni 2021, 52-64

\title{
ANDROID-BASED LEARNING MEDIA DESIGN FOR INTRODUCTION TO SUNDA CULTURE FOR EARLY CHILDREN
}

\author{
Taopik Rahman, Silmi Qurota Aeni \\ Universitas Pendidikan Indonesia \\ Corresponding e-mail: hlibrianty75@gmail.com
}

\begin{abstract}
This research aims to develop android-based learning media which aims to make children know Sundanese culture in a more effective, fun, and innovative way to introduce culture from an early age and can help the role of teachers or parents in educating and providing knowledge to children children outside the school environment in a fun way. This research uses the Design Based Research (DBR) method for the Sunda Exploration Learning Media by carrying out four steps, namely the identification and problem analysis steps by researchers and practitioners collaboratively, developing a prototype solution based on theoretical benchmarks, existing design principles and technological innovations, conducting iterative process to test and improve practical solutions, reflections to produce design principles and improve implementation of practical solutions, Sundanese Exploration Learning Media can be used in learning with cultural themes. This media was developed based on the 2013 PAUD curriculum and adapted to the needs in the field regarding the fulfillment of Sundanese cultural learning. Based on the entire research process that has been carried out, the product designed by the researcher can be applied to early childhood education learning. In addition, the product can also be easily applied by teachers and parents, because this media is presented complete with a user guide ebook that describes the explanation and how to use it. Android-based learning media is the most effective media that can be one of early childhood learning in learning something. This learning media can be used by parents and schools, schools can use this application as additional learning and parents can use this application at home or anywhere.
\end{abstract}

Keywords: Learning Media, Android, Sundanese Culture

\begin{abstract}
Abstrak
Penelitian ini bertujuan untuk mengembangkan media pembelajaran berbasis android agar anak mengenal budaya sunda dengan cara yang lebih efektif, menyenangkan, dan inovatif untuk mengenalkan budaya sejak dini, membantu peran guru atau orang tua dalam mendidik dan memberikan ilmu kepada anak-anak. di luar lingkungan sekolah dengan cara yang menyenangkan. Penelitian ini menggunakan metode Design Based Research (DBR) Media Pembelajaran Eksplorasi Sunda dengan melakukan empat langkah yaitu langkah identifikasi dan analisis masalah oleh peneliti dan praktisi secara kolaboratif, mengembangkan solusi prototipe berdasarkan tolok ukur teoritis, prinsip desain yang ada dan teknologi. inovasi, melakukan proses iteratif untuk menguji dan meningkatkan solusi praktis, refleksi untuk menghasilkan prinsip-prinsip desain dan meningkatkan implementasi solusi praktis. Media ini dikembangkan berdasarkan kurikulum PAUD 2013. Berdasarkan proses penelitian yang telah dilakukan, produk yang dirancang peneliti dapat diterapkan pada pembelajaran PAUD. Selain itu, produk ini juga dapat dengan mudah diterapkan oleh guru dan orang tua, karena media ini disajikan lengkap dengan buku panduan pengguna yang menjelaskan penjelasan dan cara penggunaannya. Media pembelajaran berbasis android merupakan media yang paling efektif yang dapat menjadi salah satu pembelajaran anak usia dini dalam mempelajari sesuatu. Media pembelajaran ini dapat digunakan oleh orang tua dan sekolah, sekolah dapat menggunakan aplikasi ini sebagai pembelajaran tambahan dan orang tua dapat menggunakan aplikasi ini di rumah atau dimana saja.
\end{abstract}

Kata Kunci: Media Pembelajaran, Android, Budaya Sunda 


\section{Introduction}

Education is a very important aspect in life, so children have the right to get education from the moment they are born. PAUD plays a role in optimizing children's growth and development as the foundation and provision for taking the next level of education.

In this study, the knowledge competencies to be achieved through thematic learning in the PAUD curriculum are Core-3 competencies (KI-3) which contain competencies to identify oneself, family, friends, educators, the surrounding environment, religion, technology, arts and culture at home, playground and PAUD units (PAUDNI, 2014). The basic competencies that researchers want to do in KI-3 are Basic Competence 3.7 (KD-3.7), which is to know the social environment (family, friends, place of residence, places of worship, culture, transportation (Suminah, nd). achieved is knowledge and skills regarding the social environment related to the life and dynamics of cultural communities such as traditional games, food and crafts. It is hoped that this media can increase and direct children's attention to what they are learning and can also help children to get to know the Sundanese culture that varied (Nurrita, 2018).

Culture in the surrounding environment is regional culture, regional culture is the basis for the development of a nation's identity (Tilaar, 2002, p.5), so it is necessary to introduce national culture to the younger generation, starting from early childhood. Juridically, Article 32 of the 1945 Constitution states that the state shall promote Indonesian national culture in the midst of world civilization by guaranteeing the freedom of the people to maintain and develop their cultural values. This cultural planting must be started as early as possible, by gradually instilling love and practicing skills repeatedly and continuously (Karwati, 2014).

In the specific objectives of early childhood education, children are able to recognize the natural environment, social environment, the role of society, and appreciate social and cultural diversity and are able to develop self-concept, positive attitude towards learning, self-control and a sense of belonging. So it is appropriate to know the culture in the surrounding environment, to be one part of learning activities that can be carried out by educators in order to preserve culture. The young generation is expected to be a generation that is proud of its own cultural traditions, loves and preserves the noble values of cultural traditions and can develop an attitude of appreciating the diversity of cultural traditions in the future (Darihastining et al., 2020).

Learning in PAUD in this globalization era faces quite complex challenges. Especially from the influence of foreign cultures that enter Indonesia, which may not be in harmony with the national culture and Indonesian regional culture which 
adheres to values, norms, ethics, customs and local culture as well as other values and principles, this affects education and Indonesian culture and is feared will erode and threaten the existence of Sundanese culture as part of the local culture of the Indonesian nation's culture, so in order to continue to exist and be strong, a way is needed to maintain it. One solution is to synergize and integrate Sundanese culture into early childhood education, which is considered a golden age, a stage that will determine a child's future, namely through Sundanese culture in the form of Sundanese philosophy or cultural values and pupuh. be a way to preserve local wisdom of Sundanese culture and as a filter from the negative impact of foreign culture, can also develop the potential of early childhood, in addition to expert opinion also shows that the values and philosophy contained in Sundanese culture are in accordance with the principles of national education goals (Kurniasih, N., Rakhmaniar, A., \& Rachman, 2021.

In line with K.D 3.7, namely the introduction of culture in the surrounding environment, researchers focused on research on Sundanese culture. In order to create learning success, it is necessary to make learning media that are in accordance with the competencies to be achieved and besides that the learning media that are made must also make children interested and motivated in learning.

In this context, game tools or media that can support children's development are needed. Basically, the best toys are selected according to the child's age, development, and interests. The right games for children can be produced by children through the help of parents and teachers (Hayati, 2017).

Learning media is a tool used as an intermediary in the teaching and learning process. In the process of using learning media, apart from being a forum, it must also have information to be conveyed ( $R$ Susilana, 2008; Rolina, n.d.). Good use of learning media can also help students absorb more information, and can also increase student motivation in learning. Along with the development of technology, the form of learning media has also experienced a shift. Interactive learning media can help users to learn independently and help users to have more motivation to learn (Puspa Putri, 2019).

Learning media that are limited to visuals and the delivery of learning materials that are only verbal so far have not been able to provide a learning experience that is in accordance with the expected competition. Children become bored quickly and do not focus on learning, because learning media are not in accordance with the characteristics of children's learning. With the appropriate and appropriate learning media, the delivery of learning materials will be more effective because it can help visualize a concept from verbal learning materials (Daryanto \& Dwicahyo, 2014).

In early childhood learning, educators should also follow the development of technology and information and are required to be able to use and utilize digital and 
modern technology such as Android-based smartphones and other media that can be used for PAUD learning needs. The existence of modern technology is very interesting and fun for children to play and learn with it. Technological advances make the world of education need innovative and creative technology-based learning media (Lestari et al., n.d.)

Technology-based games often give a negative impression because they are considered to have a negative influence on children, but in fact, games also provide many positive benefits for them, children get to know computer technology, lessons to follow directions and rules, practice problem solving and logic, train motor nerves and spatial skills, establish parent-child communication when playing together, and provide entertainment. In fact, for certain patients, game play can be used as a healing therapy (Henry, 2013)

Android-based learning media is one way to apply 21st century learning styles. The use of this kind of learning media has the potential to help improve students' academic performance in the form of learning outcomes in the cognitive domain and students' learning motivation. The implementation of learning using smartphones and tablets can have a positive impact on the cognitive, metacognitive, affective, and socio-cultural dimensions. Smartphones and tablets have the power to transform the learning experience. This type of learning media allows students to learn not limited by time and place with interesting applications (Ardiansyah \& Nana, 2020). The development of information technology plays an important role in human life, one of the technologies that is currently developing very rapidly is technology in the form of smartphones, especially those based on Android (Sanjaya, 2015). The Android platform has become so popular, it is taken seriously by game developers.

Android is an operating system for Linux-based mobile devices that includes an operating system, middleware, and applications. Android provides an open platform for developers to create their applications. Android is operating system that powers more than a billion smartphones and tablets. Because these devices make our lives so sweet, each Android version is named after a dessert (Putra et al., 2016).

Android is one of the software for mobile devices that is currently quite popular, android was developed based on linux which includes SO, middleware and applications (Gandhewar \& Sheikh, 2010). Android is currently attracting a lot of attention from both individuals and companies, with the latest versions being continuously launched. Until now there are nine versions of android starting with version 1.0, android version 1.1, android version 1.5 (Cupcake), android version 1.6 (Donut), version 2.0-2.1 (eclair), version 2.2-2.3 (froyo), version 2.3-2.3 .7 (gingerbread) until the latest android version is currently android 9.0+ (Pie) (Puspa Putri, 2019) 
According to International Data Corporation (2019), Android dominates the market with total sales reaching $87.0 \%$ and iOS $14.9 \%$. Android users can maximize the function and performance of their phones or tablets with a variety of applications. Applications that are widely circulated today are dominated by applications intended for adults, while applications that are useful and specifically intended for early childhood are still relatively few, and educational materials are still limited. However, there are several applications that have been used as existing Android-based learning media such as interactive educational applications that contain material about learning to recognize letters, numbers, colors, animals and fruits (Asniati et al., 2017) and the educational game application Kids Learning application. This is almost the same as previously mentioned, namely learning to recognize letters, colors, etc. with a more attractive appearance (Jayanti et al., 2018).

The purpose of this research is to develop an android-based learning media that aims to make children know Sundanese culture in a more effective, fun way, as well as an innovative way to introduce culture from an early age and can help the role of teachers or parents in educating and providing knowledge to students. children outside the school environment in a fun way. Learning must be based on cultural values. Culture-based learning is a shield and weapon for individuals in society, especially early childhood in their lives in this information and technology age. With the development of culture-based android media, children can recognize the identity of their own culture.

\section{Method}

This study aims to develop an android-based learning media, in order to facilitate the introduction of Sundanese culture in early childhood, therefore the researcher uses the Design Based Research (DBR) method. Design Based Research is defined as a series of approaches used with a view to generating new theories, artifacts, and practical models in explaining and potentially impacting learning in natural (naturalistic) conditions. Therefore, Design Based Research can be said to be a development method as confirmed by Van den Akker saying that Design Based Research (DBR) is development research. Therefore, Design Based Research (DBR) is commonly referred to as a research method that can be implemented in the development of learning tools. Design-based research integrates the development of solutions to practical problems in a learning environment with the identification of reusable design principles" (Hamdu et al., 2016).

From the explanation above, the researcher uses the Design Based Research (DBR) method because it is in accordance with the research objectives, namely designing, developing, and testing the feasibility of a product to overcome problems in learning through product manufacturing by integrating design and scientific 
methods as well as to test the feasibility of the product produced, namely androidbased learning media to facilitate the introduction of Sundanese culture in early childhood.

As the four stages of the Design Based Research (DBR) method that have been chosen, the researcher will carry out the following research procedures:

1. Step Identification and analysis of problems by researchers and practitioners collaboratively

This stage is the initial stage in Design Based Research. At this stage the researcher analyzes the problems and needs based on theory or literature review. Then to find out the relevance of the results of the analysis, the researchers conducted a preliminary study to schools. When the problem has been found, the researcher analyzes the problem, and conducts consultations with expert supervisors. The problem that the researchers found from the school was the limited learning media to facilitate the introduction of Sundanese culture in children. These efforts are still carried out using conventional media, tend to make children easily bored and seem monotonous. So that there is a need for research in the form of developing learning media in order to be a solution to the existing problems. Based on theoretical studies, problem findings, and the results of discussions with practitioners in the field, an agreement was obtained in the form of an Android-based learning media to facilitate the introduction of Sundanese culture in early childhood.

2. Developing prototype solutions based on theoretical benchmarks, existing design principles and technological innovations

At this stage, the researcher begins to develop a product design design that is developed. This media contains material about the introduction of Sundanese culture which is packaged in the form of adventure, children are invited to explore in the adventure like on a trip, there are three adventure trips including the first adventure containing material about traditional games, children are invited to know what games are in Sunda, adventure the second contains material on handicrafts, and the last adventure contains material on typical Sundanese food. In addition to adventures that contain material, there is a children's worksheet that is packaged in the form of a game to make it more fun, it is called looking for treasure, when the child can answer questions or complete tasks in the game, the child will get the treasure he has been looking for, at the end of the day the child will get the treasures that have been collected. Apart from having adventures and searching for treasures, this media provides information to get to know the developers of learning media. 
3. Carry out an iterative process to test and improve practical solutions

The third stage is the validation test and improvement of the product that has been designed. Experts who become validators are experts in the field of pedagogy, the field of learning media, the field of science and experts in the field of application. After going through a series of expert validation tests, a product trial will be carried out, but the article only contains the design of learning media, not yet conducted a field trial. (Cobb \& Gravemeijer, 2006)

4. Reflection to produce design principles and improve implementation of practical solutions

At this stage, a re-test is carried out to follow up on the results of the previous product revision. If there are still shortcomings, then revisions are made again. These deficiencies are then evaluated to match the specified criteria, so that in the end it produces a final product in the form of an android-based learning media to facilitate the introduction of Sundanese culture in early childhood. This trial activity was carried out successively in order to produce an android-based learning media product to facilitate the introduction of Sundanese culture in early childhood in accordance with the standard level of achievement of child development.

\section{Result and Discussion}

Learning media applications must be able to provide alternatives for children to learn and get information about Sundanese culture easily and interestingly that can be used on Android Smartphones. Previously, there were several learning media applications such as the Kids Learning application, but the existing applications contained material about animals, numbers, letters and others. In the learning media application "Explore Sundanese Culture" with the target user, namely children. The duration is unlimited, the multimedia elements consist of text, sound, images and interactivity. This learning media can help children get to know Sundanese culture which is equipped with $2 \mathrm{D}$ animated images, how to use it is to choose one of the materials that have been provided which will display images and materials that have been selected by the user. The content in this learning media application consists of 2 learning content that contains material and information about Sundanese culture and a quiz about finding treasure (Komalasari et al., 2020). There are 3 menus in the application including an adventure menu which contains three materials, there is an introduction to traditional games, food materials, and craft materials in Sundanese, then there is a treasure search menu which contains children's worksheets packaged with attractive designs, and the third There is an info menu consisting of developer information and navigation information. 
In each menu there is a narration available to clarify the material and commands in the media, more details will be described as follows:

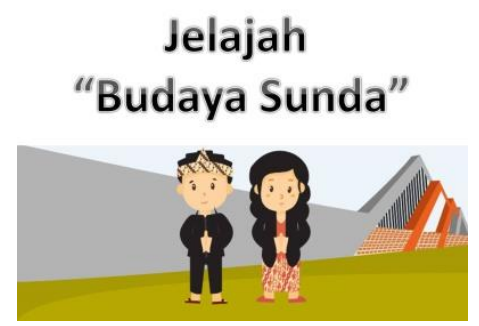

Figure 1 Main Menu

Figure 1 is the first which contains three main menus, namely the adventure menu, the treasure search menu, and the info menu.

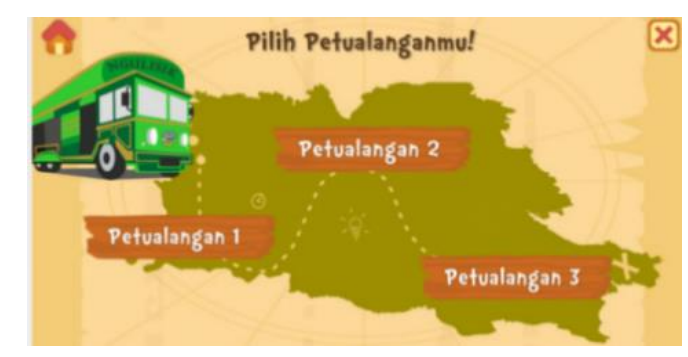

Figure 2 Adventure Menu

Figure 2 The adventure menu is material content that is packaged in a more fun form, because children can choose three materials including the introduction of traditional games, food, and crafts in Sundanese.

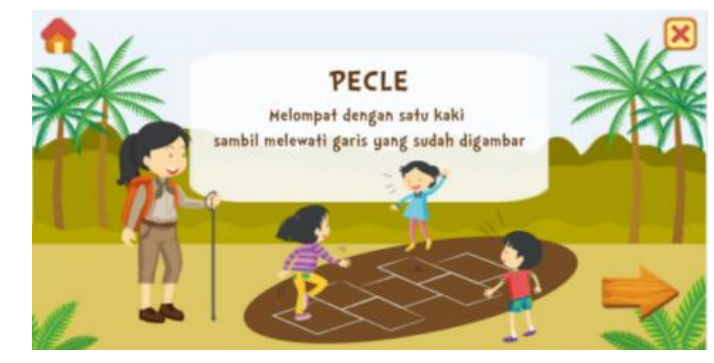

Figure 3 Traditional Game Menu

Figure 3 Traditional Game Menu, this menu contains material about the introduction of traditional games, one of the pages on the introduction of traditional games. 


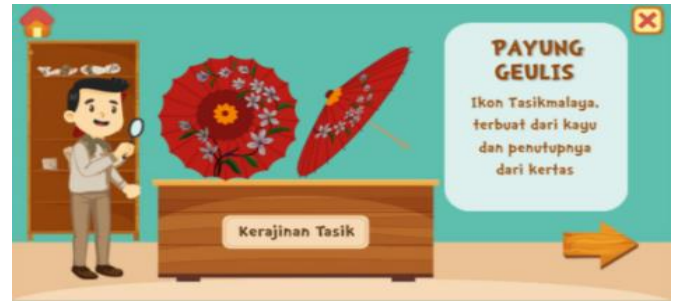

Figure 4 Craft Menu

Figure 4 shows a menu about handicrafts in Sundanese culture, so children can find out what handicrafts exist in Sundanese culture.

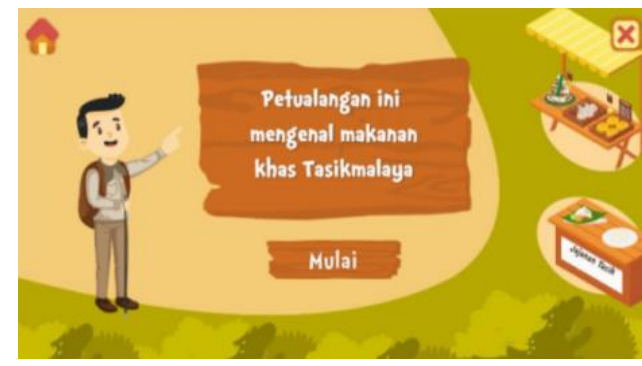

Figure 5 Menu about food

Picture 5 Contains the traditional Sundanese food menu, so from this menu children can find out what kinds of Sundanese food are

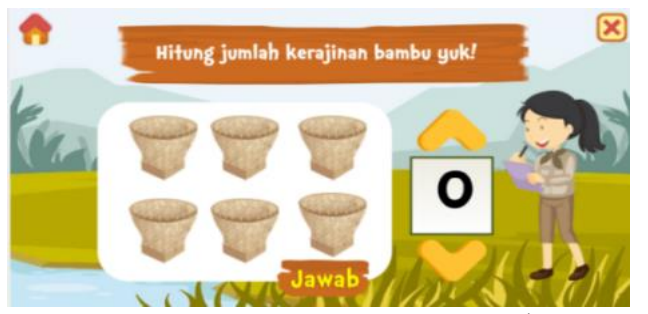

Figure 6 Treasure Search Pages

Figure 5 contains the treasure search menu, the treasure search menu contains children's worksheets that are packaged in the form of innovative games.

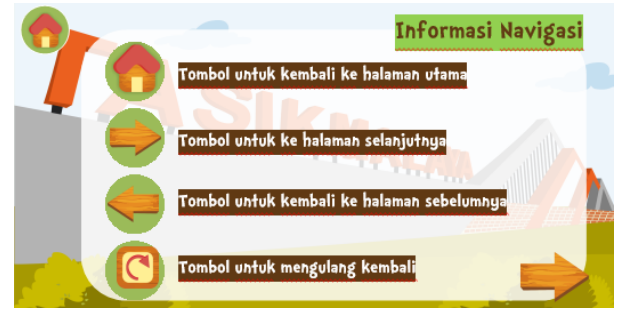

Figure 7 Application Information Menu

Figure 7 is the information menu on the application to make it easier for users to use the application.

The Sunda Exploration Learning Media can be used in learning with cultural themes. This media was developed based on the 2013 PAUD curriculum and 
adapted to the needs in the field regarding the fulfillment of Sundanese cultural learning. This learning media has been completed through the process of making designs, audio recordings, and combining content through articulate story lines, and conducting expert validation to determine product feasibility. Based on the entire research process that has been carried out, the products designed by researchers can be applied to early childhood education learning. In addition, the product can also be easily applied by teachers and parents, because this media is presented complete with a user guide ebook that describes the explanation and how to use it.

This product mixes multimedia elements such as images, sounds and animations that are designed in such a way as to be interesting and can show the material to be delivered. This is done so that the material is easily understood by children and can increase the enthusiasm and motivation of children to learn. It is hoped that this product can be used as an alternative solution in the application of multimedia learning in early childhood education. In addition, it is also hoped that children will be able to be facilitated in introducing Sundanese culture.

There are many inputs that can be used as a guide for researchers to carry out development. By using android-based learning media, users can feel many advantages compared to other types of learning references. The advantages of this media roaming Sundanese media are practical in use, easy to install on devices that are already running on the android system, the media can be used in classroom learning with teacher guidance or learning at home with parents, this android-based media is designed in such a way that it is usable by the user or friendly to the user, displayed with an attractive color presentation then adding a narration to clarify the material in the media, Media can be used repeatedly if the child does not understand the material and wants to play it again.

\section{Conclusion}

Education is very important in life, so children have the right to get education from an early age. at the age of golden age like an early age. Android-based learning media is the most effective media that can be one of early childhood learning in learning something. media Learning media Explore Sundanese Culture can be one of the media that can help children to learn Sundanese culture. Multimedia elements consist of text, sound, images and interactivity. This learning media can help children to get to know Sundanese culture such as traditional Sundanese games, handicrafts from Sundanese culture, Sundanese food. This media is very effective because it is based on Android which can be used on smartphones with the guidance and supervision of parents at home and also this media can be used repeatedly without any time duration. 
Based on the research that has been carried out, the researcher feels that this research does not stop here. With the guidance of changing times, of course the development of learning media, especially Android-based learning media, must still be done, in order to keep up with developments and produce better products from this research product. Here are some recommendations from researchers:

1. Android-based learning media to facilitate the introduction of Sundanese culture in. early childhood is expected to be an alternative for teachers or parents in introducing Sundanese culture in an innovative way.

2. Schools can use this media to develop children's learning media about Sundanese culture. In addition to schools having additional learning media, the use of android-based learning media as a result of this study helps to overcome the limitations of learning media when introducing Sundanese culture. The researcher recommends the school to continue to support future researchers who intend to develop the products developed in this research.

3. Parents can use this media so that children can find out about Sundanese culture when children are at home or anywhere and also accompany children when using Android-based learning media played via smartphones, so that media use is more optimal.

\section{References}

Ardiansyah, A. A., \& Nana, N. (2020). The Role of Mobile Learning as Innovation in Improving Student Learning Outcomes in Learning in Schools. Indonesian Journal Of Educational Research and Review, 3(1), 47-56.

Asniati, A., Pasrahmaya, W. O. H., \& Fatimah, S. (2017). Android-Based Interactive Education Applications as Learning Media for Early Childhood Education. Journal of Informatics, 5(1).

Cobb, P., \& Gravemeijer, K. (2006). Educational design research. Routledge.

Darihastining, S., Aini, S. N., Maisaroh, S., \& Mayasari, D. (2020). Use of Audio Visual Media Based on Local Cultural Wisdom in Early Childhood. Journal of Obsession: Journal of Early Childhood Education, 5(2), 1594-1602.

Daryanto, D., \& Dwicahyo, A. (2014). Thematic Learning, Integrated, Integrated Curriculum 2013. Yogyakarta: Gava Media.

Gandhewar, N., \& Sheikh, R. (2010). Google Android: An Emerging Software Platform For Mobile Devices. International Journal on Computer Science and Engineering (IJCSE), Special Issue, 6.

Hamdu, G., Lestari, A., \& Nurlaila, N. (2016). Development of Learning Tools as Curriculum Implementation 2013. Proceedings of SNPS (National Seminar on Science Education), 3, 375-380.children were not yet capable of fine motor skills 
in early childhood development which had to be developed in one of the developments. Kumara Scholar, 7(4).

Hayati, M. (2017). Designing of Educational Game Tools for Early Childhood Development Based on Islamic Values. International Conference on Education in Muslim Society (ICEMS 2017).

Henry, S. (2013). Smart With Games. Main Library Gramedia.

Jayanti, W. E., Meilinda, E., \& Fahriza, N. (2018). Educational Game "Kids Learning" as a Basic Learning Media for Early Childhood Based on Android. Journal of Informatics Equator, 6(1).

Karwati, E. (2014). Learning Development By Emphasizing Local Culture In Early Childhood Education. EduHumanities | Cibiru Campus Basic Education Journal, $6(1)$.

Komalasari, N., Hidayat, E. W., \& Aldya, A. P. (2020). MULTIMEDIA-BASED INTRODUCTION APPLICATIONS OF SUNDA LANGUAGE WITH VISUALS CONCEPT. National Journal of Informatics Engineering Education: JANAPATI, 9(1), 21-31.

Kurniasih, N., Rakhmaniar, A., \& Rachman, R. (2021). Developing the Potential of Early Childhood Through Sundanese Culture. Journal of Social Research Communication Science, 5(1), 28-36.

Lestari, N. D., Hermawan, R., \& Heryanto, D. (n.d.). DEVELOPMENT OF LEARNING MEDIA USING POWTOON FOR ELEMENTARY SCHOOL THEMATIC LEARNING. Journal of Primary School Teacher Education, 3(3), 3343.

Nurrita, T. (2018). Development of learning media to improve student learning outcomes. MISYKAT: Journal of the Sciences of the Qur'an, Hadith, Shari'ah and Tarbiyah, 3(1), 171-210.

PAUDNI, D. (2014). Guidelines for Preparation of Early Childhood Education Learning Planning. Jakarta: Ministry of Education and Culture.

Puspa Putri, D. A. (2019). Design and Build Arabic Learning Media for Early Childhood Based on Android. Technologia: Scientific Journal, 10(3), 156. https://doi.org/10.31602/tji.v10i3.2230

Putra, D. W., Nugroho, A. P., \& Puspitarini, E. W. (2016). Android-based Educational Game as a learning medium for early childhood. JIMP-Informatics Journal of Merdeka Pasuruan, 1(1).

R Susilana, C. R. (2008). Learning media: nature, development, utilization, and assessment. https:/ / books.google.co.id/books?hl=en\&lr=\&id=- 
yqHAwAAQBAJ\&oi=fnd\&pg=PR3\&dq=Susilana, + R.,+Si, + M.,+\%26+Riyana, + C. $+$

2008.+Media+learning:+nature,+development,+utilization,+and+assessment.+C V.+Discourse+Prima.\&ots=EkPp0tiu54\&sig=yMISF6rIQDD5lcwVT79xPDUyUsg \&redir_esc $=\mathrm{y} \# \mathrm{v}=$ onepage $\& \mathrm{q} \& \mathrm{f}=$ onepage $\& \mathrm{q} \& \mathrm{f}=$

Rolina, N. (n.d.). Muhyidin.(2014). Encyclopedia of Early Childhood Education, Learning Methods \& Media. Yogyakarta: Civilian People.

Sanjaya, W. (2015). Learning system planning and design. date.

Suminah, E. (n.d.). et al. 2015. Guidelines for Assessment of Early Childhood Education Learning. Jakarta: Director General of PAUD. 